\title{
STUDENTS' ATTITUDES TO SELECTED SUBJECTS IN SECONDARY ECONOMIC EDUCATION
}

\author{
Kateřina Berková, Kristýna Krejčová \\ University of Economics, Czech Republic \\ E-mail: katerina.berkova@vse.cz, kris.krejcova@gmail.com \\ Jaromír Novák \\ University of Economics in Bratislava, Slovakia \\ E-mail: jaromir.novak@euba.sk
}

\begin{abstract}
Students' motivation is one of the key factors that determine their school success. It is closely linked to their attitudes toward individual school subjects. This research analyzes four crucial dimensions of students' subject-related attitudes (practical importance, difficulty, popularity and curriculum contents attractiveness) in the secondary economic education in the Czech Republic and Slovakia in the international context. The research focused on the four dimensions of students' attitudes $(n=573)$ toward four major school subjects (economics, accounting, mathematics and the mother tongue) at business academies. It analyzes the data from the questionnaires using the Spearman Correlation Coefficient, the non-parametric Kruskal-Wallis test and the modification of Tukey's method for multiple comparisons. The results show that the popularity of a school subject significantly correlates with its curriculum contents attractiveness and practical importance. However, the difficulty of school subjects did not influence their popularity in a negative way, which opens several questions for further research in the area.
\end{abstract}

Keywords: economic education; students' attitudes; motivation in economic school subjects; school subject popularity; school subject difficulty.

\section{Introduction}

Educational processes at all levels and types of school have one general goal - to maximize school success and educational attainment of an individual. Students' general cognitive abilities, general motivational factors and special, subject-related interests are the main determinants of their potential to prosper in these processes (Schiefele, Krapp, \& Winteler, 1992). Two previous studies (Berková \& Krejčová, 2016; Berková, Krejčová, Králová, Krpálek, Krpálková Krelová, \& Kolářová, 2018) examined the role of cognitive abilities and their relation to motivation, learning outcomes and attitudes to a teacher. According to their findings, the motivation of the average students increases thanks to their teachers' expertise, their ability to develop thinking and exposition to the curriculum, whereas the above-average students perceived only teachers' expertise and exposition to the curriculum as motivational. The research in the previous article provided the basis for the current research, which deals especially with students' interests and subject-related attitudes.

General definitions of motivation refer to the sum of processes or dynamism that energize and target behavior of an individual to reach something desirable or avoid something undesirable (Plháková, 2010). Ceauşu (2018) stated that motivation was a result of the encounter between the biologic and the social and operated as a dynamic and plastic system providing socialadaptive program of the subject. An individual specification of motivational processes arises from the unique structure of human needs (Maslow, 1954). 
Kateřina BERKOVÁ, Kristýna KREJČOVÁ, Jaromír NOVÁK. Students' attitudes to selected subjects in secondary economic education

PROBLEMS

OF EDUCATION

IN THE $21^{\text {st }}$ CENTURY

Vol. 78, No. 1,2020

10

Considering practical implications of the theoretical construct, motivation is observable in a form of specific relations to various dimensions of reality. In educational processes, the subject-related interests interact with emotional phenomena such as a sense of school belonging (Ferreira, Cardosob, \& Abrantesc, 2011) and are transformed into self-regulative processes that significantly modify learning efficiency (Popa, 2015). The concept of academic self-efficacy (Pajares, 1996) expressed the interplay of all these processes. Reflecting the importance of selfview for students' academic success, the research presented in this article builds on students' self-reflective statements. Tossavainen and Juvonen (2015) used this research approach when they examined the motivation of primary and secondary school students to the subjects of mathematics and music. They described the students' learning motivation with respect to their enjoyment of the subjects and their perceptions about the importance and usefulness of the subjects. Their research also investigated the respondents' view of the difficulty of the subjects, the popularity of the subjects, the students' self-competence in the subjects, and their gender. The research revealed a relation between the students' attitudes to the subject of mathematics and their learning motivation. The research of Huber and Seidel (2018) also supported this approach to the research of motivation to learn. The researchers concluded that teachers tended to overlook the diversity of students' attitudes, perceiving them mostly in simplistic, general categories.

There are close relations between students' attitudes to the subjects they study and their learning motivation. Attitudes to a subject and the overall level of motivation may determine learning outcomes more intensively than the level of intelligence even in the education of math (Murayama, Pekrun, Lichtenfeld, \& Vom Hofe, 2013). Therefore, an extreme set of mind such as math anxiety may have a distortive impact on educational attainment (Luttenberger, Wimmer, \& Paechter, 2018). Tossavainen and Juvonen (2015) confirmed in their research that the students' attitudes to one subject (math) can affect attitudes to another subject (music). Their methodology and research results were inspirational for the current research, which examines the relations between the students' attitudes toward the chosen economic and non-economic subjects.

Subject-related attitudes are largely influenced by the approach of a teacher who modulates students' behavior engagement and thus influences learning outcomes (Leon, Medina-Garrido, \& Núñez, 2017), using specific techniques such as deep reasoning questions and feedback (Jurik, Gröschner, \& Seidel, 2014). The study by Prokop, Tuncer, and Chudá (2007) found that a teacher's identity also strongly affects the students' attitudes toward the teacher. Adu, Galloway, and Olaoye (2014) did research in the field of economic education and proved that students' perception of their teachers influences their attitude toward economics.

Identification and measuring the influence of students' attitudes to their school subjects, their teachers and the overall educational process have become an important part of educational research. Related studies usually focus on subject-specific areas of teaching and learning at schools. For example, several studies examined students' attitudes toward science (school subjects such as biology, geography and so like), in the Czech and Slovak educational environments (Kubiatko, Janko, \& Mrázková, 2012; Prokop, Tuncer, \& Chudá, 2007). The results of the former research showed that the popularity of geography in the Czech Republic, as well as the year of study, significantly influenced the perception of the subject. Other studies stressed the link between the perception of a subject and usefulness of the acquired knowledge for students' lives etc.

Many researchers have studied learning motivation as well as students' attitudes towards school subjects and their school success. However, they are still the subject of discussions and their relations are not clear. The OECD study (2003,p. 81) states: "it can be argued that attitudes should relate to achievement, an interesting question of causality arises here because it is not obvious if success in learning engenders better attitudes or if a positive attitude to school is 
effectively a factor in motivating students to learn." According to PISA results (OECD, 2003), the students may be motivated to study mathematics by its perceived importance to future education or to careers. The current empirical research builds on these results and extends the methodology to finding relations between the chosen economic and non-economic subjects.

The current empirical research is based on PISA results (OECD, 2012), which show students' solidarity to their schools throughout 28 countries around the whole world. The Czech Republic and Slovakia prove to be significantly under the OECD average. The PISA results were also used in a comparative study of Bruner, Keller, Wenger, Fischbach, and Lüdtke (2018) dealing with domain-general and domain-specific measures of achievement, learning strategies, engagement and motivation. Having compared responses of 15-year-old students at schools from 81 countries, they found substantial differences in achievement. Interestingly, differences in learning strategies, motivation and engagement were less significant. We can presume that research conclusions about motivation tend to have a more general validity than conclusions about achievement. Therefore, the research into students' attitudes to school subjects and their influence on the students' motivation to learn can bring useful recommendations for pedagogical practice.

This research focuses primarily on students' attitudes toward two major economic subjects (economics and accounting) studied at business academies (i. e. the most common type of school in economic secondary education in both the Czech Republic and Slovakia) in comparison with their attitudes to two other major non-economic subjects (mathematics and the mother tongue) studied at the same schools. Hausmannová (2015) researched some aspects of students' attitudes to major economic-related school subjects at business academies in the Czech Republic on a sample of 1,733 respondents. Economics proved to be a more popular subject than accounting, and it was regarded as considerably less difficult and slightly more important for the students' future careers than accounting. The methodology of this research builds on the research by Hrabal and Pavelková (2010), who suggested using six dimensions for measuring students' attitudes, half of which examined students' perception of the evaluated subject and the other half reflected selected aspects of students' self-evaluation.

\section{Research Aim}

The current research deals with students' interests and subject-related attitudes. The aim of the research was to find how students perceive the subjects of economics, accounting, mathematics and their mother tongue (i.e. the Czech and Slovak languages) as regards their practical importance, popularity, levels of difficulty and attractiveness of their curriculum contents. Based on the aforementioned approach to the research problem, the correlations between these four dimensions of students' attitudes for each of the subjects were analyzed separately. Furthermore, the similarities and differences in the dimensions of students' attitudes between the selected subjects were identified.

\section{Research Hypotheses}

The hypotheses that result from the aim of the research were as follows:

1. There is a positive dependency between popularity, importance and curriculum contents attractiveness of each subject.

2. A negative dependence proves to exist between difficulty and other dimensions of the students' attitude (popularity, importance and curriculum contents attractiveness) to each selected subject.

3. Students perceive the selected subjects - as regards the monitored dimensions of their attitudes - differently. 
PROBLEMS

OF EDUCATION

IN THE $21^{\text {st }}$ CENTURY Vol. 78, No. 1,2020

12

Research Methodology

\section{General Background}

This empirical research was a partial section of the comprehensive research which focused on the attitude of secondary school students to the selected subjects in study programs related to economics as well as the factors influencing students' motivation in connection with the selected subjects: economics; accounting; mathematics; and the mother tongue (the Czech or Slovak languages, which are very similar regarding both grammar and vocabulary). The examples of good practice showed that students had very similar feelings for mathematics and accounting and their school success was very similar in both of these subjects. Given that economics and accounting are the main graduation subjects at business academies, they are both very important for the attempts to improve the quality of teaching and learning and to prepare the students for the final examinations at this type of school. The empirical research examined whether the students' attitudes to the subjects were independent or whether there were some links between the students' attitudes towards the subjects (Tossavainen \& Juvonen, 2015). A deeper knowledge of these contexts is very helpful for improving the processes of teaching and learning in these economic subjects, for which a certain level of knowledge of mathematics and the mother tongue is vital. Accounting uses many mathematical operations and forms a logical system. Both accounting and economics use specific terminology, so it is important that students have a good command of their mother tongue in order for them to understand and be able to discuss the subject matter correctly. For the above reasons, the combination of these four subjects was chosen for the analyses.

The research was based on two comprehensive types of research conducted in the Czech Republic (Hrabal \& Pavelková, 2010; Hausmannová, 2015), the results of which may be, considering population, regarded as generally valid; they pertain to students' attitudes to individual subjects both on the general level and in the context of study programs related to economics. Their approach to the research problem inspired the chosen research design as well.

\section{Sample}

The research comprised secondary schools from the Czech Republic and Slovakia, which guarantee and provide high-quality economic education within the scope of a study program at a business academy. The sample of secondary schools was created on the basis of a premeditated selection whose main criterion was a close cooperation of the schools with the two main scientific workplaces in the area - the University of Economics in Prague and the University of Economics in Bratislava. The respective cooperation pertains to provision of pedagogical internships to future teachers - students of the study program of Teaching of Economic Subjects. Therefore, the teachers in these schools are supposed to approach the educational process in an innovative manner and exploit not only traditional but also modern teaching methods. They should show the university students examples of good teaching practice and base the educational process more on experience-oriented, active learning. The aforementioned educational requirements are further reinforced with respect to the changing strategy of educational policies in both countries. They reflect contemporary evolution of the educational contents and ways of teaching and learning. As regards secondary school students, their education is supposed primarily to develop competencies required for their active civil, professional and personal lives. This should lead to the increasing students' interest in the study field through formation of positive attitudes to the key subjects of the study program and reaching the educational objectives and related competencies in an efficient, targeted manner. It has been proven (Berková, Krejčová, Králová, Krpálek, Krpálková Krelová, \& Kolářová, 
2018) that the students of business academies with higher motivation can develop their higher cognitive skills better.

The total number of 7 secondary schools from the capital cities of both countries (Prague and Bratislava) participated in the research. The main research comprised 577 students in their last (fourth) or penultimate (third) years of study. The number of valid observations was 573, which was due to some failures to answer questions and provision of ambiguous answers. Therefore, 4 respondents were excluded from the overall research sample. The sample of students was also created on the basis of intentional selection. This method was applied in order to obtain answers from students who already have enough experience with economic education, thus being able to evaluate their attitude to selected subjects in economic education more impartially. Representation of the students from the Czech Republic is lower and constitutes $28.6 \%$ of the sample. The Slovak students represent $71.4 \%$ of the sample. The research sample consists of 392 women (i.e. $68.4 \%$ ) and 181 men (i.e. 31.6\%). The respondents, who were third-year and fourth-year students of secondary schools, were $17-19$ years old. The data were analyzed comprehensively, for the sample as a whole. The results from both countries were evaluated and processed together, considering the almost identical educational procedures and objectives in the respective area. For the structure of the research sample, see Table 1.

\section{Table 1}

Structure of the research sample

\begin{tabular}{ccc}
\hline Group & Absolute frequency & Relative frequency (\%) \\
\hline 3rd year, Czech Republic & 83 & 14.5 \\
\hline 4th year, Czech Republic & 81 & 14.1 \\
\hline 3rd year, Slovakia & 206 & 36.0 \\
\hline 4th year, Slovakia & 203 & 35.4 \\
\hline Total & 573 & 100 \\
\hline
\end{tabular}

Instrument and Procedures

The research was conducted using the questioning method. As the research was quantitative, the questionnaire for the respective purpose was created based upon two questionnaires previously used for similar purposes (Berková, Krejčová, Králová, Krpálek, Krpálková Krelová, \& Kolářová, 2018; Berková, Borůvková, \& Lízalová, 2018). It was distributed to the secondary schools and among the students in the written form from April to June 2018. The collection of data at each of the selected schools was performed by the researchers in person or with the assistance of the secondary school teachers. This approach guaranteed a higher rate of return. It was recommended that the students should respond as impartially as possible, specifying that the collected data were subject to a high level of confidentiality and anonymity while being used solely for the publishing of research papers.

The questionnaire contained five main sections pertaining to the (a) student's general motivation within the scope of economic education; (b) student's attitudes to the teacher; (c) student's attitudes to the selected subjects (economics, accounting, mathematics and the mother tongue); (d) time necessary for the student's preparation at home; and (e) demographic data about the respondent (i.e. gender, secondary school, grades from the selected subjects, interest in the chosen study field, and factors influencing the student's choice of secondary school). The questionnaire was not newly developed, but it was based on the structure of the questionnaires used in the previous two research studies in the areas of economics-related secondary education (Berková, Krejčová, Králová, Krpálek, Krpálková Krelová, \& Kolářová, 2018) and tertiary education (Berková, Borůvková, \& Lízalová, 2018). For this reason, no validation and feasibility 
Kateřina BERKOVÁ, Kristýna KREJČOVÁ, Jaromír NOVÁK. Students' attitudes to selected subjects in secondary economic education

PROBLEMS

OF EDUCATION

IN THE $21^{\text {st }}$ CENTURY

Vol. 78, No. 1,2020

14

tests were performed. The reliability of the questionnaire was verified in the pilot phase. Due to the fact that the research is extensive and comprises a high number of variables, this paper focuses solely on a single part of the research - student's attitudes to the selected subjects and search for the interrelations between the attitudes and their dimensions.

The following four dimensions of students' attitudes were determined: practical importance of the subject; popularity of the subject; attractiveness of the curriculum contents of the subject; and its perceived level of difficulty. The students evaluated these dimensions of their attitudes not only for the two major subjects in their economic education, i.e. economics and accounting. They also expressed their opinions about two major non-economic subjects in which it was possible to find similarities with the two economic subjects, i.e. mathematics and the mother tongue (Czech, Slovak). mathematics was selected considering the fact that accounting represents a discipline based mainly on the logical system exploiting mathematical algorithms. On the contrary, economics is a socio-scientific discipline based more on verbal logic and description of economic phenomena, so it could be presumed that students' attitudes to this subject might be related to their attitudes toward their mother tongue. Both of these subjects are significantly influenced by the students' literacy, ability to understand texts, search for information and work with it.

The data representing ordinal variables as the measurement of attitudes was based on the scale featuring values between -2 and 2 . The value of -2 represented the lowest intensity of attitude while 2 represented the highest intensity of a student's attitude to the subject and its dimensions. As regards the practical importance, popularity and curriculum contents attractiveness of a subject, a higher value represents a more positive evaluation presented by a student. In case of the difficulty of a subject, a higher value represents a higher level of demand, i.e. a more negative attitude.

\section{Data Analysis}

The obtained data were analyzed using the Spearman Correlation Coefficient $(r)$. This test was applied with respect to the unproven normality of data and nature of the applicable variables. The above-mentioned test allowed for the determination of relations between students' attitudes to each of the selected subjects.

The analysis of similarities/differences within and between the two pairs of the subjects (economics versus the mother tongue and accounting versus mathematics) was performed with respect to the fact that data normality had not been proven using the non-parametric Kruskal-Wallis test. A paired comparison test (a modification of Tukey's method for multiple comparisons) - the Tukey-Kramer Procedure - was used in order to determine the subjects in which students' attitudes showed similarities and differences.

Null (statistical) hypotheses were defined as follows:

1. No positive dependence proves to exist between popularity, importance and attractiveness of each subject.

2. No negative dependence proves to exist between difficulty and other dimensions of attitudes (popularity, importance and attractiveness) to each selected subject.

3. No differences prove to exist in the students' perception of the selected subjects as regards the analyzed attitudes. 


\section{Research Results}

Correlation of the Importance, Popularity and Attractiveness in Case of Each Subject according to the Students' Attitudes

The Spearman Correlation Coefficient revealed correlations between the three dimensions of the students' attitudes to the selected subjects of economics, accounting, mathematics and the mother tongue (the Czech and Slovak languages).

As regards economics, the research revealed a positive correlation of practical importance, popularity and attractiveness of the curriculum contents - at the significance level of 5\%. This means that if the subject of economics features practical importance for students, it is also attractive - and vice versa.

In the case of economics, the strength of the positive correlation was as follows: popularity - attractiveness $(r=.67 ; p<.01)$; practical importance - popularity $(r=.529 ; p<$ $.01)$; practical importance - attractiveness $(r=.478 ; p<.01)$. The detailed results are presented in Table 2.

\section{Table 2}

\section{Correlation of the attitudes to economics}

\begin{tabular}{lcccccccc}
\hline & \multicolumn{2}{c}{ Importance } & \multicolumn{2}{c}{ Popularity } & \multicolumn{2}{c}{ Difficulty } & \multicolumn{2}{c}{ Attractiveness } \\
\cline { 2 - 9 } & $p$ & $r_{s}$ & $p$ & $r_{s}$ & $p$ & $r_{s}$ & $p$ & $r_{s}$ \\
\hline Importance & & & .001 & .529 & .720 & -.015 & .001 & .478 \\
\hline Popularity & .001 & .529 & & & .0356 & -.088 & .001 & .670 \\
\hline Difficulty & .720 & -.015 & .0356 & -.088 & & & .509 & -.028 \\
\hline Attractiveness & .001 & .478 & .001 & .670 & .509 & -.028 & & \\
\hline
\end{tabular}

In the case of accounting, the research revealed a positive correlation of reviewed attitudes - practical importance, popularity and attractiveness of the curriculum contents - at the significance level of $5 \%$. The research proved that if the subject of accounting is popular with secondary school students, it also has practical importance and attractiveness, which applies in any given order - like in the case of economics. However, the correlations are stronger than in the case of economics, as documented by the following values of the Spearman Correlation Coefficient for popularity - attractiveness $(r=.75 ; p<.01)$; practical importance - popularity $(r=.595 ; p<.01)$; practical importance - attractiveness $(r=.628 ; p<.01)$. For more details, see Table 3.

\section{Table 3}

\section{Correlation of the attitudes to accounting}

\begin{tabular}{lcccccccc}
\hline & \multicolumn{2}{c}{ Importance } & \multicolumn{2}{c}{ Popularity } & \multicolumn{2}{c}{ Difficulty } & \multicolumn{2}{c}{ Attractiveness } \\
\cline { 2 - 9 } & $p$ & $r_{s}$ & $p$ & $r_{s}$ & $p$ & $r_{s}$ & $p$ & $r_{s}$ \\
\hline Importance & & & .001 & .595 & .265 & .047 & .001 & .628 \\
\hline Popularity & .001 & .595 & & & .770 & -.012 & .001 & .750 \\
\hline Difficulty & .265 & .047 & .770 & -.012 & & & .413 & .413 \\
\hline Attractiveness & .001 & .628 & .001 & .750 & .413 & .413 & & \\
\hline
\end{tabular}


PROBLEMS

OF EDUCATION

IN THE $21^{\text {st }}$ CENTURY

Vol. 78, No. 1,2020

As regards mathematics, the research proved - at the significance level of $5 \%-$ major interrelations between: popularity - attractiveness $(r=.735 ; p<.01)$; practical importance popularity $(r=.638 ; p<.01)$; practical importance - attractiveness $(r=.655 ; p<.01)$. It may be stated that if mathematics is popular with students, it is also considered to be attractive and important for their practical life. This applies in any order. For more details, see Table 4.

Table 4

Correlation of the attitudes to mathematics

\begin{tabular}{lcccccccc}
\hline & \multicolumn{2}{c}{ Importance } & \multicolumn{2}{c}{ Popularity } & \multicolumn{2}{c}{ Difficulty } & \multicolumn{2}{c}{ Attractiveness } \\
\cline { 2 - 9 } & $p$ & $r_{s}$ & $p$ & $r_{s}$ & $p$ & $r_{s}$ & $p$ & $r_{s}$ \\
\hline Importance & & & .001 & .638 & .0003 & .150 & .001 & .655 \\
\hline Popularity & .001 & .638 & & & .040 & .086 & .001 & .735 \\
\hline Difficulty & .0003 & .150 & .040 & .086 & & & .004 & .118 \\
\hline Attractiveness & .001 & .655 & .001 & .735 & .004 & .118 & & \\
\hline
\end{tabular}

As regards the mother tongue, the following correlations prove to be generally valid at the significance level of $5 \%$ : popularity - attractiveness $(r=.67 ; p<.01)$; practical importance popularity $(r=.494 ; p<.01)$; practical importance - attractiveness $(r=.471 ; p<.01)$. This case also documented the fact that if the mother tongue is considered to be a popular subject, it is also attractive for the students and they perceive its curriculum contents as practically important. For more details, see Table 5.

\section{Table 5}

Correlation of the attitudes to the mother tongue

\begin{tabular}{lllllllll}
\hline & \multicolumn{1}{l}{ Importance } & \multicolumn{2}{c}{ Popularity } & \multicolumn{2}{c}{ Difficulty } & \multicolumn{2}{c}{ Attractiveness } \\
\cline { 2 - 8 } & $p$ & $r_{s}$ & $p$ & $r_{s}$ & $p$ & $r_{s}$ & $p$ & $r_{s}$ \\
\hline Importance & & & .001 & .494 & .001 & .133 & .001 & .471 \\
\hline Popularity & .001 & .494 & & & .009 & .109 & .001 & .670 \\
\hline Difficulty & .001 & .133 & .009 & .109 & & & .001 & .064 \\
\hline Attractiveness & .001 & .471 & .001 & .670 & .001 & .064 & & \\
\hline
\end{tabular}

The strongest correlation of the analyzed dimensions of students' attitudes was found for the pair of popularity and curriculum attractiveness of each subject. At the significance level of $5 \%$ we reject the null hypothesis 1 on the non-existence of positive dependence of popularity, practical importance and attractiveness in case of each subject. 
Correlation of the Difficulty with Other Dimensions of the Students' Attitudes (Importance, Popularity and Attractiveness) in Case of Each Subject

In the case of economics, the negative correlation was proven (at the significance level of $5 \%)$ with a single pair of reviewed attitudes - difficulty and popularity $(p=.035)$. As regards interpretation of the significance of relations based on the p-value, it may be generally stated that if the subject is difficult for students, it is less popular (and vice versa). However, the value of the correlation coefficient is very low; it does not reach even the lowest required value of .4 $(r=-.088)$. For the detailed results of $\mathrm{p}$-values and correlation coefficients, see Table 2.

In the case of accounting, no negative correlation between difficulty and other dimensions of the students' attitudes to the subject was proven at the significance level of $5 \%$. For more details (i.e. p-values of individual attitudes and correlation coefficients), see Table 3.

The subject of mathematics - unlike both economic subjects - features completely different results. At the significance level of $5 \%$ the research proved the correlation of the difficulty of the subject with the other attitudes - its practical importance $(p=.0003)$; popularity of the subject ( $p=.04)$; and attractiveness of the curriculum contents of the subject $(p=.004)$. The Spearman Correlation Coefficient was used to determine a positive correlation between the difficulty of the subject of mathematics and the other dimensions of attitudes. However, the correlation coefficient values are very low and do not reach the required minimum value of .4 - in case of the following combinations of the analyzed dimensions of students' attitudes: (a) difficulty - practical importance $(r=.15)$; (b) difficulty - popularity $(r=.086)$; (c) difficulty attractiveness $(r=.118)$. For the detailed results, see Table 4 . It is, however, to be stated that a rather surprising result pertains to the positive correlation between the difficulty of the subject of mathematics and the other dimensions of attitudes toward this subject - unlike the subject of economics in case of which a negative correlation was determined between its difficulty and popularity (even though it was very small). The positive correlation means that even if the subject of mathematics is difficult for students, it is popular, attractive and practically important at the same time.

In the case of the mother tongues (the Czech and Slovak languages), the research provedat the significance level of $5 \%$ - certain correlations between difficulty and the other dimensions of attitudes, i.e. difficulty and practical importance of the subject $(p=.001)$; difficulty and popularity of the subject $(p=.009)$; and difficulty and attractiveness of the curriculum contents of the subject $(p<.01)$. The Spearman Correlation Coefficient showed positive correlations like in the case of mathematics. However, the values of correlation coefficients are very low and, once again, they do not reach the minimum value of .4, in case of which the result might be considered as generally valid. The values for individual combinations of the dimensions of students' attitudes were as follows: (a) difficulty and practical importance of the subject ( $r=$ $.133)$; (b) difficulty and popularity $(r=.109)$; (c) difficulty and attractiveness $(r=.064)$. For more details, see Table 5.

In the case of the mother tongue, the research also revealed positive correlation of its difficulty with the other dimensions of attitudes. It means that if students perceive the mother tongue as a difficult school subject, it is also popular and practically important. As regards both mathematics and the mother tongue, the aforementioned result might be explained by the fact that these subjects are generally important for everyone. Students are aware of the fact that they will need both these subjects - to a certain extent - not only for their professional careers, but also in their everyday lives. Therefore, they might associate them with the importance which reinforces the difficulty of these subjects. This importance and difficulty are given by the depth of the curriculum contents, as these subjects are not discussed only on a superficial level. Furthermore, it might result from the fact that these subjects already form a part of primary education, so students are already familiar with their fundamentals and might regard the present 
PROBLEMS

OF EDUCATION IN THE $21^{\text {st }}$ CENTURY Vol. 78 , No. 1,2020

18

teaching level as difficult (they can see how much progress they made, and what the subjects actually comprise, etc.). Practical importance might also be emphasized by the fact that the school-leaving examination in the mother tongue is compulsory and a compulsory examination in mathematics is being planned; furthermore, these subjects are taught in all types of primary and secondary schools. This proves to be contrary to economics (in this case, the negative correlation was proven for the pair of difficulty and popularity of the subject), which might be related to the position of the discipline in the society. Based on the aforementioned facts, it might be stated that in case of mathematics and the mother tongue students show more tolerance to their difficulty than in case of economics (due to their position in the society).

At the $5 \%$ level of significance, the null hypothesis 2 was not rejected. The negative dependence was found between the difficulty and popularity of the subject of economics.

\section{Similarities and Differences of the Selected Subjects with Respect to the Analyzed Dimensions of the Students' Attitudes}

Firstly, a review of significant differences between subjects based on each analyzed dimension of students' attitudes was conducted on the level of $n=573$. The results document the fact that the students evaluated the subjects differently with respect to their practical importance, popularity, difficulty and curriculum contents attractiveness; nevertheless, certain similarities of students' attitudes toward the subjects were found as well.

The differences between the subjects with respect to the students' attitudes $(p<.01)$ were found on the general level - at the significance level of 5\%. In addition, the differences between the subjects applicable to the partial dimensions of students' attitudes were determined using mean values. For the respective results, see below:

The students perceive the practical importance of the subject differently for mathematics and the mother tongue. The economics-related subjects differ from non-economic subjects, but without differences in importance between them. At the significance level of 5\%, students perceive the practical importance of economics (mean value: .923) and accounting (mean value: .777) identically while the mother tongue (mean value: .335) and mathematics (mean value: -.754 ) are perceived completely differently. Furthermore, students regard economics as the most practically important subject while mathematics ranks last. Even though mathematics is - in comparison with the other subjects - evaluated as the least important for the economic practice, the difficulty of this subject is, by contrast, in a positive correlation with its popularity and practical importance; however, this correlation value is very low. That might be related to the position of this subject in people's everyday lives, their motivations and set objectives for the future (i.e. students expect more extensive and deeper knowledge in mathematics than in economics-related subjects). On the other hand, in the context of economic practice, students do not perceive the subject of mathematics as so significant (to the same extent) as economicsrelated subjects.

The students perceived the popularity of the subjects differently within the group of the economic subjects, i. e. there was a difference between economics (mean value: .377) and accounting (mean value: .187). The students regard economics as more popular than accounting. In addition, the popularity of economics also differs from mathematics (mean value: -.729) and the mother tongue (mean value: .101). As regards the subject of accounting, a difference was determined solely in comparison with the subject of mathematics. Similarly, a difference in popularity was revealed between mathematics and the mother tongue. The similarity was proven for the popularity of the subjects of accounting and the mother tongue. These two subjects are on the identical level of students' popularity.

The students perceive the difficulty differently between mathematics and the other subjects. The students regard mathematics as the least difficult (mean value: - .268). Considering 
the aspect of statistical significance, the research proved similarity between the economicsrelated subjects; according to the mean values, economics (mean value: .094) proves to be less difficult for the students than the subject of accounting (mean value: .157). Furthermore, the research revealed a similarity in the students' attitudes between economics and the mother tongue (mean value: -.024). It may be stated that there is parity between both of the economicsrelated subjects, and between the subject of economics and the mother tongue. As regards its difficulty, the subject of mathematics proves to differ from the other subjects.

As for the attractiveness of the curriculum contents, all of the analyzed subjects are perceived differently. This documents the fact that each subject, i.e. economics (mean value: .490), accounting (mean value: .20), mathematics (mean value: -.010), and the mother tongue (mean value: -.08 ), has a different level of interest for the students. The most interesting subject is economics. For a comprehensive review of correlations between the subjects by mean values, see Table 6.

\section{Table 6}

Rank of the subjects according to the students' attitudes

\begin{tabular}{lllll}
\hline Rank & Importance & Popularity & Difficulty & Attractiveness \\
\hline 1. & Economics & Economics & Economics & Economics \\
\hline 2. & Accounting & Accounting & Accounting & Accounting \\
\hline 3. & Mother tongue & Mother tongue & Mother tongue & Mother tongue \\
\hline 4. & Mathematics & Mathematics & Mathematics & Mathematics \\
\hline
\end{tabular}

At the $5 \%$ level of significance, the null hypothesis 3 was not rejected. The differences were found in the case of the attractiveness of the curriculum content. As regards the curriculum contents attractiveness, the students perceived the subjects rather differently.

\section{Discussion}

The aim of this empirical research was to find how students perceived the subjects of economics, accounting, mathematics and their mother tongue (i.e. the Czech and Slovak languages) as regards their practical importance, popularity, levels of difficulty and attractiveness of their curriculum contents. The research primarily focused on the analysis of the correlations between these four dimensions of the students' attitudes toward each of the subjects separately. Furthermore, it identified the similarities and the differences in the dimensions of the students' attitudes between the selected subjects.

The practical importance, popularity and curriculum contents attractiveness within each individual subject feature positive correlations - as regards the subjects of economics, accounting, mathematics and the mother tongue. The correlations are the strongest in the cases of mathematics and accounting, followed by economics and the mother tongue. The difficulty does not correlate with these dimensions of students' attitudes in the case of accounting. As regards economics, its difficulty features a very low level of negative correlation with its popularity; however, the respective correlation is very weak. On the contrary, a positive correlation between difficulty and the other attitudes was determined in the cases of mathematics and the mother tongue. Nevertheless, the correlation values were very low. The subject of economics proved to be the most practically important, popular and attractive for the students. The similarity between economics-related subjects was significant as regards their practical importance and 
Kateřina BERKOVÁ, Kristýna KREJČOVÁ, Jaromír NOVÁK. Students' attitudes to selected subjects in secondary economic education

PROBLEMS

OF EDUCATION

IN THE $21^{\text {st }}$ CENTURY Vol. 78 , No. 1,2020

20

difficulty. Considering popularity, a certain similarity was identified between the subjects of accounting and the mother tongue. As for difficulty, a certain similarity was identified between the students' attitudes toward the mother tongue and economics. Considering attractiveness, all the subjects proved to differ from one another significantly.

Some of these findings might be considered as quite surprising. Greater difficulty of a school subject could be supposed to lead to its decreasing popularity among students, and vice versa. The results of the research show that this does not necessarily have to be the case, definitely not with our respondents. Hrabal and Pavelková (2010) even argue against some teachers' attempts to make their subject more attractive and popular with students by lowering the requirements in terms of the set objectives and learning outcomes, or on the contrary, warn the teachers not to demotivate students by making their subject too difficult. In this respect, it could be considered as a desired state to find that students do not automatically regard difficulty and popularity of a subject as opposites. We agree with Hausmannová (2015) that if teachers set favorable conditions in the process of teaching and learning, students can regard even most difficult tasks as relatively easy to accomplish. We can conclude that it is of vital importance for teachers to reach such a level of difficulty of their subjects that is appropriate for their students (i.e. the highest possible level of difficulty that cannot be increased any more without a considerable decrease in students' motivation). This is also in line with the facts found out by Latham and Locke (1991). In that case, students will regard even a relatively difficult subject as popular and attractive. Whether the students regard their subjects as popular and attractive is linked with their motivation (Tossavainen \& Juvonen, 2015). These relations were also examined by PISA (OECD, 2003). In these aspects, a new question arises to verify the link between the popularity of the subject and the students' motivation to learn. In this respect, this current research brings new knowledge and opens up new research questions.

An overall preference of economics was proven also by the research of Hausmannová (2015). Economics was perceived as more popular, less difficult and slightly more important than accounting. The researcher proved negative dependency between the popularity and the difficulty of both these subjects. In this current research, this relation was confirmed only in the case of economics; what is more, with a very low value of the correlation coefficient. The students' perception of the popularity and difficulty of a school subject does not have to be contradictory if a teacher sets a level of difficulty that is appropriate in terms of students' knowledge and skills, and provides the class with adequate conditions of teaching and learning.

Considering the inner factors of school success, the subject-specific interests interplay with general motivational variables and cognitive abilities (Schiefele, Krapp, \& Winteler, 1992). This current research revealed relations between practical importance, popularity and curriculum contents attractiveness. This conclusion leads to a recommendation for teachers to show practical importance of the contents of their subjects to their students. In this way, the teacher may significantly influence the subject's popularity and attractiveness. This interconnectedness of a teacher's impact on students' subject interests via stimulating behavioral engagement was described by Leon, Medina-Garrido, and Núñez (2017) and Berková and Krejčová (2016).

A comparison of the results of the studies dealing with students' attitudes and a teacher's influence on them leads to a remarkable paradox. Although the motivational factors may affect learning outcomes more than a level of intelligence even in Math (Muryama et al., 2015), teachers tend to overview a diversity of students' attitudes, perceiving them too simplified (Huber \& Seidel, 2018). Considering these relations, it is not surprising that educational outcomes may be radically transformed by undesirable psychological states such as math anxiety (Luttenberger, Wimmer, \& Paechter, 2018). The research depicted important dimensions of subject-related attitudes that should be reflected by teachers. Moreover, the findings of specific relations between the attitudes toward different subjects (e.g. the similarity of accounting and the mother tongue in terms of popularity, the similarity of economic-related subjects regarding their practical importance and difficulty) may also be used in the area of career counselling. 
The novelty of the research presented in this article was in dividing students' attitudes toward school subjects into four categories. The main contribution of the research can be seen especially in the context of the study plans for the students in economic study fields. However, the results of the current research may be transferred to further research of students' attitudes and motivation in other study fields as well.

\section{Conclusions}

The research analyzed four important dimensions of students' attitudes to the selected school subjects and their interrelations. The research results proved that the popularity of a school subject, which is one of the crucial factors of students' motivation influencing their tendency to deep learning significantly correlates with its curriculum contents attractiveness and practical importance. However, it does not necessarily have to be negatively influenced by the difficulty of the subject although several previous research studies showed that it often happens. Therefore, further research should focus more on the main factors that influence how students perceive the difficulty of a school subject. It might be interesting to analyze to what extent it is dependent on the level of requirements set by the teacher or how the difficulty of a school subject is influenced by the way they perceive the difficulty of other subjects. Another aspect worth analyzing is to what extent a teacher can influence the perceived difficulty of a subject by creating a stimulating learning environment, or by showing students the practical importance of the subject matter. It might also be interesting to research whether the perceived difficulty of a school subject influences the students' results in the subject and vice versa.

Positive students' attitudes to school subjects stimulate their motivation to study the subject matter more deeply. Therefore, it seems important for teachers to pay closer attention to their students' attitudes and their analysis with a view to influencing them with their choice of appropriate learning outcomes and attractive curriculum contents as well as suitable teaching and learning activities. Together with creating a supportive learning environment in class, they can positively influence their students' attitudes, thus increasing their learning motivation, which will finally lead to their better school results.

\section{Acknowledgements}

This research was supported by the Project No. IGS VŠE F1/7/2018, the Project VŠE No. IP 100040 and the Project KEGA No. 005EU-4/2019.

\section{References}

Adu, E. O., Galloway, G., \& Olaoye, O. (2014). Teachers' characteristics and students' attitude towards economics in secondary schools: Students' perspectives. Mediterranean Journal of Social Sciences, 5(16), 455-462. https://doi.org/10.5901/mjss.2014.v5n16p455

Berková K., Borůvková J., \& Lízalová L. (2018). Motivation of students of economic and technical study programmes as a tool of competitiveness of universities and colleges: Empirical study. Journal on Efficiency and Responsibility in Education and Science, 11(4), 72-77. https://doi.org/10.7160/ eriesj.2018.110401

Berková, K., Krejčová, K., Králová, A., Krpálek, P., Krpálková Krelová, K., \& Kolářová, D. (2018). The Conceptual four-sector model of development of the cognitive process dimensions in abstract visual thinking. Problems of Education in the 21st Century, 76(2), 121-139. http://www. scientiasocialis.lt/pec/node/1116

Berková, K., \& Krejčová, K. (2016). Effect of teachers' abilities on students' motivation with varying levels of intellectual abilities in the economics. Journal on Efficiency and Responsibility in Education and Science, 9(3), 81-87. https://doi.org/10.7160/eriesj.2016.090304 
Kateřina BERKOVÁ, Kristýna KREJČOVÁ, Jaromír NOVÁK. Students' attitudes to selected subjects in secondary economic education

PROBLEMS

OF EDUCATION

IN THE $21^{\text {st }}$ CENTURY Vol. 78 , No. 1,2020

22

Brunner, K., Keller, U., Wenger, M., Fischbach, A., \& Lüdtke, O. (2018). Between-school variation in students' achievement, motivation, affect, and learning strategies: Results from 81 countries for planning group-randomized trials in education. Journal of Research on Educational Effectiveness, 11(3), 452-478. https://doi.org/10.1080/19345747.2017.1375584.

Ceauşu, F. (2018). Effects of motivation on the learning activity. Revista Romaneasca pentru Educatie Multidimensionala, 10(2), 6-27. https://doi.org/10.18662/rrem/42

Ferreira, M., Cardosob, A. P., \& Abrantesc, J. L. (2011). Motivation and relationship of the student with the school as factors involved in the perceived learning. Procedia - Social and Behavioral Sciences, 29, 1707-1714. https://doi.org/10.1016/j.sbspro.2011.11.416

Hausmannová, H. (2015). Postoje žáků obchodních akademii k ekonomickým predmétům: diplomová práce. [Business academy students' attitudes toward economic subjects: diploma thesis]. Prague: Vysoká škola ekonomická v Praze.

Hrabal, P., \& Pavelková, I. (2010). Jaký jsem učitel. [What kind of a teacher I am]. Prague: Portál.

Huber, S. A., \& Seidel, T. (2018). Comparing teacher and student perspectives on the interplay of cognitive and motivational affective student characteristics. PLOS ONE, 13(8), e0200609. https:// doi.org/10.1371/journal.pone.0200609

Jurik, V., Gröschner, A., \& Seidel, T. (2014). Predicting students' cognitive learning activity and intrinsic learning motivation: How powerful are teacher statements, student profiles, and gender? Learning and Individual Differences, 32, 132-139. http://dx.doi.org/10.1016/j.lindif.2014.01.005

Kubiatko, M., Janko, T., \& Mrázková, K. (2012). The influence of gender, grade level and favourite subject on Czech lower secondary school pupils' perception of geography. International Research in Geographical and Environmental Education, 21(2), 109-122. https://doi.org/10.1080/103820 46.2012.672675

Latham, G. P., \& Locke, E. A. (1991). Self-regulation through goal setting. Organizational Behavior and Human Decision Processes, 50, 212-247.

Leon J., Medina-Garrido, E., \& Núñez, J. L. (2017). Teaching quality in math class: The development of a scale and the analysis of its relationship with engagement and achievement. Frontiers in Psychology, 8, 895.

Luttenberger, S., Wimmer, S., \& Paechter, M. (2018). Spotlight on math anxiety. Psychology Research and Behavior Management, 11, 311-322.

Maslow, A. H. (1954). Motivation and Personality. New York: Harper and Row.

Murayama, K., Pekrun, R., Lichtenfeld, S., \& Vom Hofe, R. (2013). Predicting long-term growth in students' mathematics achievement: The unique contributions of motivation and cognitive strategies. Child Development, 84(4), 1475-1490.

Tossavainen, T., \& Juvonen, A. (2015). Finnish primary and secondary school students' interest in music and mathematics relating to enjoyment of the subject and perception of the importance and usefulness of the subject. Research Studies in Music Education, 37(1), 107-121.

Pajares, F. (1996). Self-efficacy beliefs in academic settings. Review of Educational Research, 66(4), 543578. https://doi.org/10.3102/00346543066004543

Plháková, A. (2010). Učebnice obecné psychologie. [Textbook of general psychology]. Prague: Academia.

Popa, D. (2015). The relationship between self-regulation, motivation and performance at secondary school students. Procedia - Social and Behavioral Sciences, 191, 2549-2553. https://doi. org/10.1016/j.sbspro.2015.04.410

Prokop, P., Tuncer, G., \& Chudá, J. (2007). Slovakian students' attitudes toward biology. Eurasia Journal of Mathematics, Science and Technology Education, 3(4), 287-295.

OECD. (2003). Mathematics teaching and learning strategies in PISA, PISA: OECD Publishing, 176 p. Retrieved 10/11/2019 from: https://www.oecd-ilibrary.org/docserver/9789264039520-en. pdf? expires $=1573914856 \& \mathrm{id}=\mathrm{id} \&$ accname$=$ guest $\&$ checksum $=49$ A7472FD3E181C4CFDDF 53CAF767209

Schiefele, U., Krapp, A., \& Winteler, A. (1992). Interest as a predictor of academic achievement: A meta-analysis of research. In K. A. Renninger, S. Hidi, \& A. Krapp (Eds.). The role of interest in learning and development (pp. 183-212). Hillsdale, NJ, US: Lawrence Erlbaum Associates. 
Kateřina BERKOVÁ, Kristýna KREJČOVÁ, Jaromír NOVÁK. Students' attitudes to selected subjects in secondary economic education

Received: September 20, 2019

Accepted: January 15, 2020

PROBLEMS

OF EDUCATION

IN THE $21^{\text {st }}$ CENTURY

Vol. 78 , No. 1, 2020

23

Cite as: Berková, K., Krejčová, K., \& Novák, J. (2020). Students' attitudes to selected subjects in secondary economic education. Problems of Education in the $21^{s t}$ Century, 78(1), 9-23. https://doi.org/10.33225/pec/20.78.09

\begin{tabular}{|ll|}
\hline $\begin{array}{l}\text { Kateřina Berková } \\
\text { (Corresponding author) }\end{array}$ & Ph.D., Assistant Professor at Department of Economic Teaching Methodology, \\
& Faculty of Finance and Accounting, University of Economics, Prague, W. \\
Churchilla Sq. 4, Prague, 130 67, Czech Republic. & E-mail: katerina.berkova@ve.cz \\
& Website: https://ffu.vse.cz/english/departments/economic-teaching-methodology \\
& ORCID: 0000-0002-6158-0171 \\
\hline Kristýna Krejčová & Ph.D., Assistant Professor at Department of Economic Teaching Methodology, \\
& Faculty of Finance and Accounting, University of Economics, Prague, W. \\
& Churchilla Sq. 4, Prague, 130 67, Czech Republic. \\
& E-mail: kris.krejcova@gmail.com \\
& Website: https://ffu.vse.cz/english/departments/economic-teaching-methodology \\
& ORCID: 0000-0002-7909-4649 \\
Jaromír Novák & PhD., Assistant Professor at Department of Pedagogy, Faculty of National \\
& Economy, University of Economics in Bratislava, Dolnozemská cesta 1, Bratislava \\
& E52 35, Slovakia \\
& E-mail: jaromir.novak@euba.sk \\
Website: https://nhf.euba.sk/en/departments/department-of-pedagogy/about- \\
department \\
ORCID: 0000-0002-4666-9047
\end{tabular}

